ISSN 2541-0598 ((Print))

ISSN 2541-1217 (Oniline)
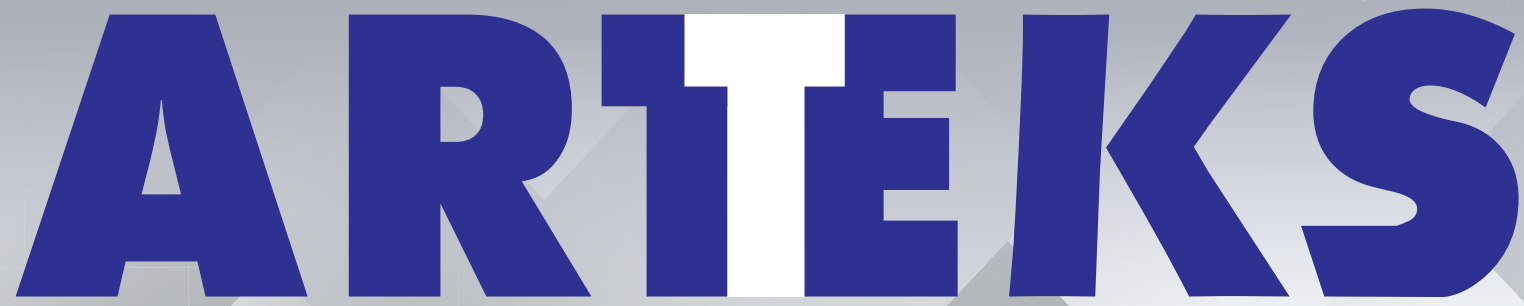

J U RNAL

T E K N I K

ARS I T E K T U R

Media Komunikasi Para Arsitek dan Publikasi Hasil Penelitian Maupun Hasil Karya Arsitektur

\title{
APRIL 2020
}
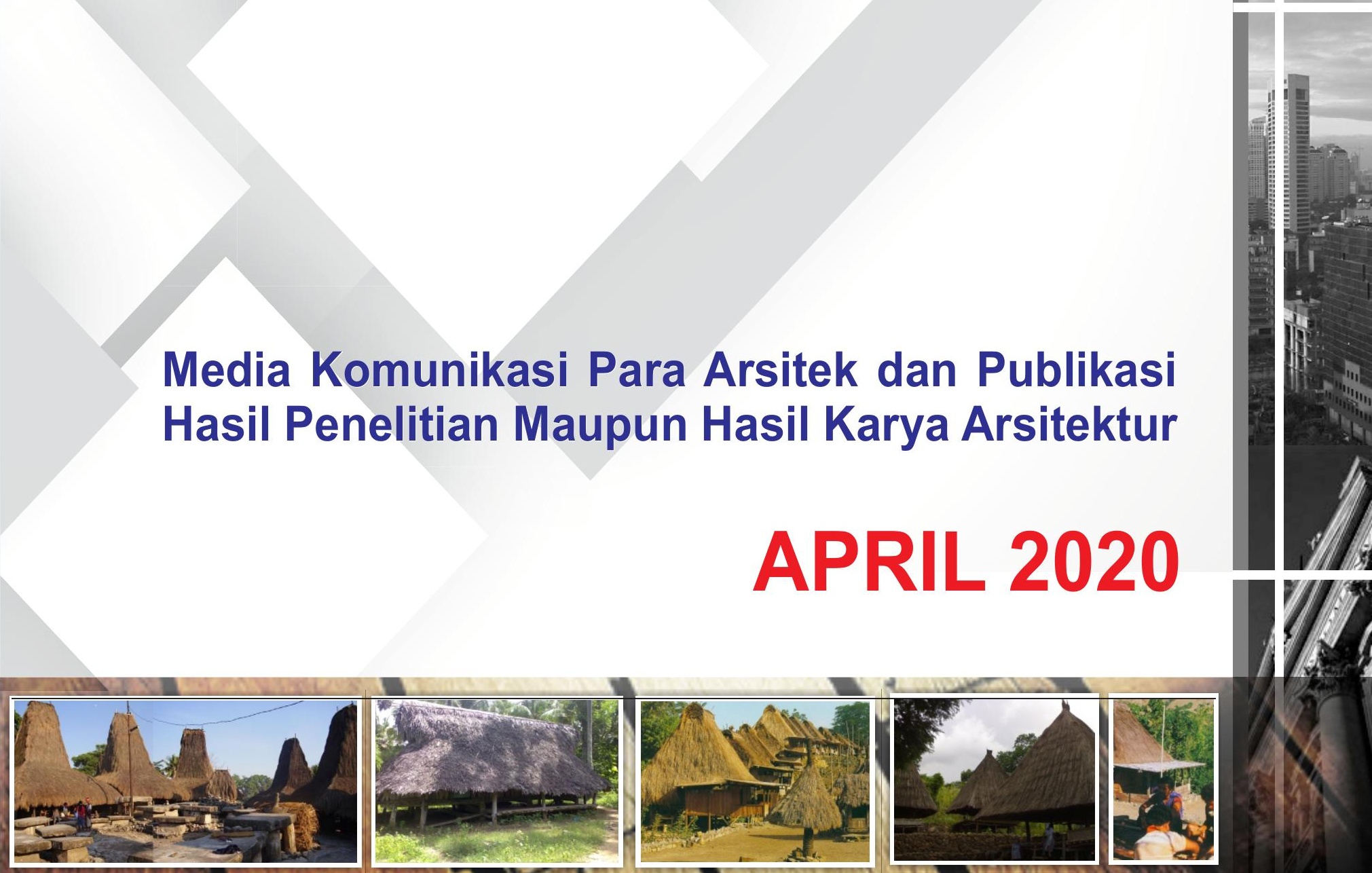

ARTEKS | VOLUME 5 | IISSUE 1 | O1 1134 I JANUARY - APRIL 2020 


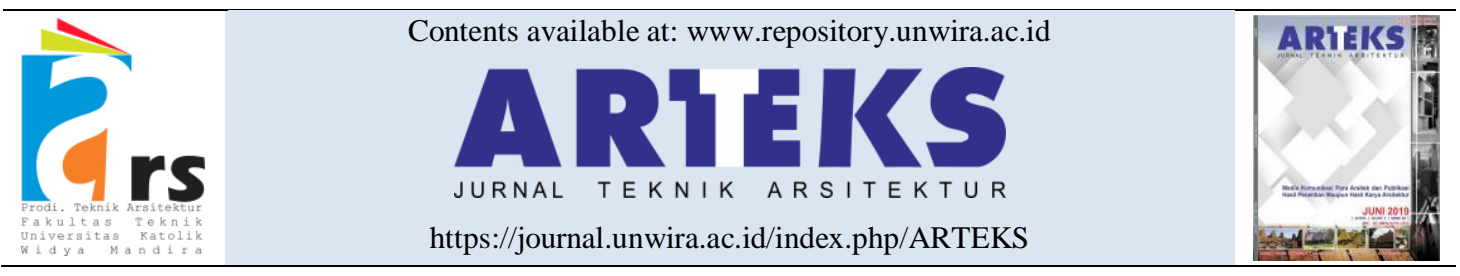

Volume 5 Issue 1 April 2020

doi: http://doi.org/10.30822/arteks.v5i1

\section{EDITORIAL TEAM}

\section{CHAIRMAN OF THE EDITORIAL BOARD [EDITORIAL IN-CHIEF]}

Reginaldo Christophori Lake, Department of Architecture, Faculty of Engineering, Universitas Katolik Widya Mandira, Indonesia [Publons ID: 3184757, Scopus ID: 57205435058, Sinta ID: 5978294]

\section{CO-EDITORS}

Ignatius Herliyanto, Department of Architecture, Faculty of Engineering, Universitas Katolik Widya Mandira, Indonesia

Pilipus Jeraman, Department of Architecture, Faculty of Engineering, Universitas Katolik Widya Mandira, Indonesia [Sinta ID: 668820]

Richardus Daton, Department of Architecture, Faculty of Engineering, Universitas Katolik Widya Mandira, Indonesia [Sinta ID: 6666038]

Robertus Mas Rayawulan, Department of Architecture, Faculty of Engineering, Universitas Katolik Widya Mandira, Indonesia [Sinta ID: 666034]

Herman Florianus Harmans, Department of Architecture, Faculty of Engineering, Universitas Katolik Widya Mandira, Indonesia [Sinta ID: 6666035]

Donatus Ara Kian, Department of Architecture, Faculty of Engineering, Universitas Katolik Widya Mandira, Indonesia [Sinta ID: 6666032]

Benediktus Boli, Department of Architecture, Faculty of Engineering, Universitas Katolik Widya Mandira, Indonesia [Sinta ID: 6666031]

Kristiana Bebhe, Department of Architecture, Faculty of Engineering, Universitas Katolik Widya Mandira, Indonesia [Sinta ID: 6666033]

\section{COMMISSIONING EDITORS}

Prof. Tarcicius Wahyu Subroto, M.Eng., Ph. D, Department of Architecture Engineering and Planning, Faculty of Engineering, Universitas Gadjah Mada, Indonesia [Scopus ID: 6506071603, Sinta ID: 6016385]

Prof. Josef Prijotomo, M.Arch., Department of Architecture, Faculty of Engineering, Universitas Katolik Parahyangan, Indonesia [Scopus ID: 55467073400, Sinta ID: 6040310]

Prof. Dr. -Ing. Gagoek Hardiman, Department of Architecture and Urban Study, Faculty of Engineering, Universitas Diponegoro, Indonesia [Scopus ID: 55898352600, Sinta ID: 6080252]

Prof. Yandi Andri Yatmo, M.Arch., Ph. D, Department of Architecture, Faculty of Engineering, Universitas Indonesia [Scopus ID: 24774175300, Sinta ID: 60325449]

Assoc. Prof. Purnama Salura, Department of Architecture, Faculty of Engineering, Universitas Katolik Parahyangan, Indonesia [Scopus ID: 56054264700, Sinta ID: 5982279]

\section{INTERNATIONAL ADVISORY EDITORAL BOARDS}

REGIONAL ADVISORY EDITORIAL ASIA-PACIFIC

Prof. Ar. Hj. Mustapha Bin Mohn Salleh, FPAM., MIID., ASEAN, APEC Architect, University Malaysia Kelantan (UMK) and City University Malaysia

Prof. Iwan Sudradjat, MSA., Ph. D, Department of Architectur, Institut Teknologi Bandung, Indonesia [Scopus.doc., Sinta ID: 6008058]

Assoc. Prof. Johannes Widodo, Ph. D, Department of Architecture, National University of Singapore, Republic of Singapore [Publons ID: 2890953, Scopus ID: 35794021500] 


\section{REGIONAL ADVISORY EDITORIAL ASIA-PACIFIC}

Assoc. Prof. Yao-Ru Chen, Ph. D, Cheng Shiu University Taiwan, Kaoshsiung City, Taiwan

[Scopus ID: 5593099800]

REGIONAL ADVISORY EDITORIAL AUSTRALIA

Assoc. Prof. Dr. Julie C. Nichols, University of South Australia [Publons ID: 2367265, Scopus ID: 57208867249]

ESSAYS AND REVIEWS EDITOR

Prof. Dr. -Ing., L. M. F. Purwanto, Department of Architecture, Faculty of Engineering, Universitas Katolik Soegijapranata, Indonesia [Scopus ID: 57204532925, Sinta ID: 6005052]

Assoc. Prof. Rawiwan Oranrtmanee, Ph. D, Chiang Mai University, Thailand [Scopus ID: 56024262500]

Stephanie Clarissa, Department of Architecture, Faculty of Engineering, Universitas Katolik Parahyangan, Indonesia [Scopus ID: 57201876258]

Mahatmanto, Department of Architecture, Universitas Kristen Duta Wacana, Indonesia [Scopus ID: 56841551300, Sinta ID: 6689952]

Dr. Elvis Alebertus Bin Toni, Universitas Katolik Widya Mandira, Indonesia [Sinta ID: 6668588]

Dr. Aleksius Madar, Universitas Katolik Widya Mandira, Indonesia [Sinta ID: 6198801]

\section{BUILDING REVIEWS EDITOR}

Agung Murti Nugroho, Ph. D, Department of Architecture, Faculty of Engineering, Universitas Brawijaya, Indonesia [Scopus: 35183690500, Sinta ID: 6030692]

Sidhi Wiguna Teh, Department of Architecture, Faculty of Engineering, Universitas Tarumanagara, Indonesia [Scopus: 57204942653, Sinta ID: 6656155]

Yuliana Bhara Mberu, Department of Architecture, Faculty of Engineering, Universitas Katolik Widya Mandira, Indonesia [Sinta ID: 6707113]

Apridus Lapenangga, Department of Architecture, Faculty of Engineering, Universitas Katolik Widya Mandira, Indonesia

Ria Rangga Bhajowawo, Department of Architecture, Faculty of Engineering, Universitas Katolik Widya Mandira, Indonesia

\section{REVIEWERS BOARD}

Prof. Antariksa, Department of Architecture, Faculty of Engineering, Universitas Brawijaya, Indonesia [Scopus ID: 57193347228, Sinta ID: 6024065]

Assoc. Prof. Lim Yong Long, Ph. D, Universiti Teknologi Malaysia [Scopus ID: 56463499700]

En-Yu Huang, Ph. D, National Cheng Kung University, Taiwan

Assoc. Prof. Dr. Kengo Hayashi, Ph. D, Institute of Industrial Science, The University of Tokyo, Japan [Publons ID: 2507413, Scopus ID: 56921071000]

Dr. Yohanes Djarot Purbadi, Department of Architecture, Faculty of Engineering, Universitas Atma Jaya Yogyakarta, Indonesia [Publons ID: 3176695, Scopus ID: 56324031900, Sinta ID: 5975807]

Assoc. Prof. Dr. Rumiati Rosaline Tobing, Department of Architecture, Faculty of Engineering, Universitas Katolik Parahyangan, Indonesia [Scopus: 57204474225, Sinta ID: 6704965]

Prof. James Erich Dominggus Rilatupa, Department of Architecture, Faculty of Engineering, Universitas Kristen Indonesia [Scopus ID: 56460292500, Sinta ID: 5992154]

Dr. Yohanes Basuki Dwisusanto, Department of Architecture, Faculty of Engineering, Universitas Katolik Parahyangan, Indonesia [Publons ID: 3444580, Scopus: 57194068693, Sinta ID: 5999711]

Dr. Johannes Adiyanto, Department of Architecture, Faculty of Engineering, Universitas Sriwijaya, Indonesia [Publons ID: 3348874, Scopus ID: 57215526362, Sinta ID: 6004651]

Prof. Arief Sabarudin, Center for Housing and Settlement Research and Development, Ministry of Public Work and Public Housing, Republic of Indonesia

Prof. Titien Saraswati, Department of Architecture, Universitas Kristen Duta Wacana, Indonesia [Sinta ID: 5989437]

Prof. Paramita Atmodiwirjo, Department of Architecture, Faculty of Engineering, Universitas Indonesia [Publons ID: 2977794, Scopus ID: 36184976900, Sinta ID: 6032545]

Prof. Respati Wikantiyoso, Department of Architecture, Faculty of Engineering, Universitas Merdeka Malang, Indonesia [Publons ID: 3014004, Scopus ID: 57191840875, Sinta ID: 5972522] 


\section{REVIEWERS BOARD}

Assoc. Prof. Dr. A. Tutut Subadyo, MSIL, Department of Architecture, Universitas Merdeka Malang, Indonesia [Scopus ID: 57194451262, Sinta ID: 6094324]

Prof. Sudaryono, Department of Architecture, Faculty of Engineering, Universitas Gadjah Mada, Indonesia [Scopus ID: 56293797500,_Sinta ID: 6017946]

Dr. Revianto Budi Santosa, Department of Architecture, Faculty of Engineering, Universitas Islam Indonesia [Scopus ID: 53865516200,_Sinta ID: 6196628]

Dr. Fermanto Lianto, Department of Architecture, Faculty of Engineering, Universitas Tarumanagara, Indonesia [Publons ID: 2088943, Scopus ID: 57194055988, Sinta ID: 5988874]

Assoc. Prof. Tutin Aryanti, Ph. D, Department of Architecture, Universitas Pendidikan Indonesia [Publons ID: 2127965, Scopus ID: 55846210200, Sinta ID: 258178]

Assoc. Prof. Dr. Popi Puspitasari, Department of Architecture, Faculty of Engineering, Universitas Trisakti, Indonesia [Publons ID: 2660698, Scopus ID: 57200722335, Sinta ID: 5983609]

Assoc. Prof. Hanson Endra Kusuma, Ph. D, Department of Architecture, Institut Teknologi Bandung, Indonesia [Scopus ID: 55909907900, Sinta ID: 5996012]

Yohannes Firzal, Ph. D, Department of Architecture, Faculty of Engineering, Universitas Riau, Indonesia [Publons ID: 3180395, Scopus ID: 57201348064, Sinta ID: 6083072]

Dr. Krismanto Kusbiantoro, Department of Architecture, Universitas Kristen Maranatha, Indonesia [Sinta ID: 5985861]

Dr. Joyce Marcella Laurens, Department of Architecture, Faculty of Engineering, Universitas Kristen Petra, Indonesia [Scopus doc., Sinta ID: 5984284]

Dr. Alwin Suryono Sombu, Department of Architecture, Faculty of Engineering, Universitas Katolik Parahyangan, Indonesia [Sinta ID: 6098846] 


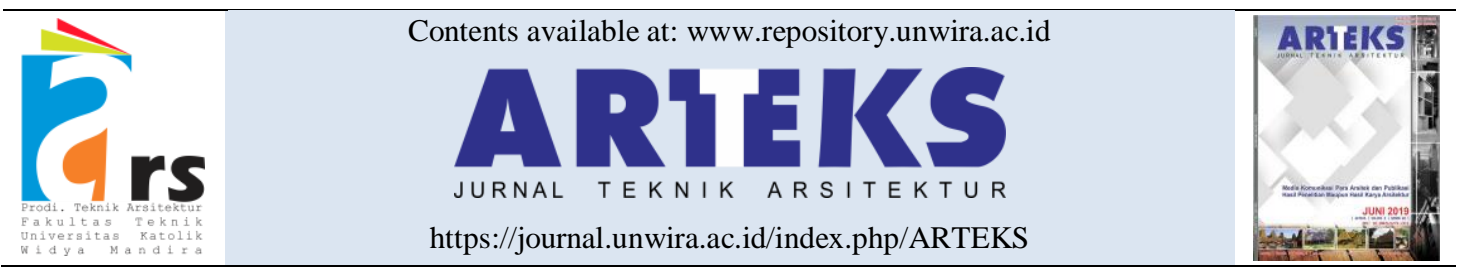

Volume 5 Issue 1 April 2020

doi: http://doi.org/10.30822/arteks.v5i1

\section{AIMS AND SCOPE}

ARTEKS : Jurnal Teknik Arsitektur is a medium of scholarly publication published by the Widya Mandira Catholic University's Faculty of Engineering Architecture Study Program, an institution of Catholic higher education institutions, in collaboration with Indonesia Architect Association of [IAI] NTT Region, Indonesian Assisted Environment Research Association [IPBLI] and Indonesia Writers Guild [SATUPENA RI]. It serves several goals i.e. being a medium of communication, dissemination and exchange of information, and a medium of publishing scholarly research in the field of Architecture. ARTEKS : Jurnal Teknik Arsitektur covers general as well as specific issues in the field of Architecture such as: (1) Theory, history, architectural design; (2) Architectural science and technology; (3) Urban architecture and design; (4) House and housing architecture; (5) Interior and exterior design. The journal, serving as a forum for the study of Indonesian architecture, supports focused studies of particular themes and interdisciplinary studies in relation to the subject. It has become a medium of exchange of ideas and research findings from various traditions of learning that have interacted in the scholarly manner. All material submitted to ARTEKS : Jurnal Teknik Arsitektur is subject to rigorous peer reviews using the 'double-blind' referee process. The Editorial Board, which was enhanced by regional editors in around seven countries, welcomes contributions from all over the world. This is the express purpose of the ARTEKS : Jurnal Teknik Arsitektur to influence the future of architecture and its acceptance nationally and internationally by publishing innovative contributions to every aspect of architectural business.

The manuscript articles should be submitted by online in MS Word / Open Office / PDF file format to Editorial Office throught Online Submission interface at: https://journal.unwira.ac.id/index.php/ARTEKS/index. The Author must read the author guidelines of this journal first before submitting a manuscript.

\section{PUBLICATION INFORMATION}

ARTEKS : Jurnal Teknik Arsitektur [p-ISSN: 2541-0598; e-ISSN: 2541-1217].

Short journal title: ARTEKS J. Tek. Arsit.

For year 2020, 3 issues [Volume 5, Issue 1 (April), Issue 2 (August), and Issue 3 (December)] are scheduled for publication with 6-12 articles per issue. Commencement of publication: December 2016.

ARTEKS : Jurnal Teknik Arsitektur, initialized as ARTEKS, is published freely open access of fulltext PDF articles via journal website [https://journal.unwira.ac.id/index.php/ARTEKS/index]. The ARTEKS : Jurnal Teknik Arsitektur is published by the Widya Mandira Catholic University's Faculty of Engineering Architecture Study Program jointly with Indonesia Architect Association of [IAI] NTT Region, Indonesian Assisted Environment Research Association [IPBLI] and Indonesia Writers Guild [SATUPENA RI].

ARTEKS : Jurnal Teknik Arsitektur has been indexed and abstracted by: SINTA Grade 3 [Science and Technology Index], DOAJ [Directory of Open Access Journals], GARUDA [Garba Rujukan Digital], ICI [Index Copernicus International], Dimension - Digital Science, BASE [Bielefed University Library], IOS [Indonesian One Search], and other reputable indexers.

\section{Crossef $_{10.30822 / \text { arteks.v5i1 }}$}

\section{Editorial office:}

Kampus Teknik Universitas Katolik Widya Mandira

Jl. San Juan, No. 01 - Penfui Timur, Kota Kupang, Nusa Tenggara Timur

Phone : (0380) 8041884/085239151912

Email : $\quad$ tarsitekturunwira@gmail.com/arteks@unwira.ac.id;

Website : https://journal.unwira.ac.id/index.php/ARTEKS/index

Accreditation : Sinta 3 based on SK 30/E/KPT/2019 


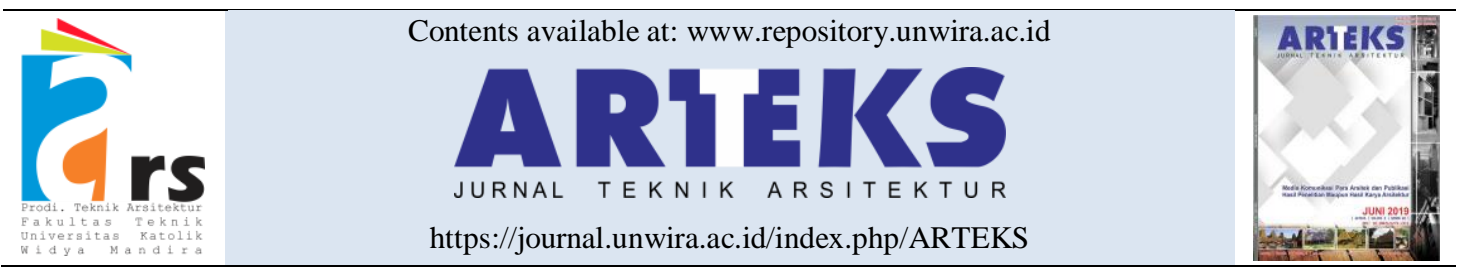

Volume 5 Issue 1 April 2020

doi: http://doi.org/10.30822/arteks.v5i1

\section{INDEXING AND ABSTRACTING}

ARTEKS : Jurnal Teknik [p-ISSN: 2541-0598; e-ISSN: 2541-1217] has been covered [indexed and abstracted] by following indexing services:

1. SINTA Grade 3 [Science and Technology Index]

2. DOAJ [Directory of Open Access Journals]

3. ICI [Index Copernicus International]

4. CrossRef Member

5. GARUDA [Garba Rujukan Digital]

6. Dimension - Digital Science

7. IOS [Indonesian One Search]

8. Google Scholar

9. ROAD ISSN

10. WorldCad OCLC

11. Mendeley

12. Scilit

13. Wizdom.ai

14. BASE [Bielefeld University Library]

15. Academia.edu

16. ResearchGate

17. Zenodo

18. Publons

19. MORAREF [Ministry of Religious Affairs Reference]

20. PKP Index

For detail please visit here: https://journal.unwira.ac.id/index.php/ARTEKS/indexing. 


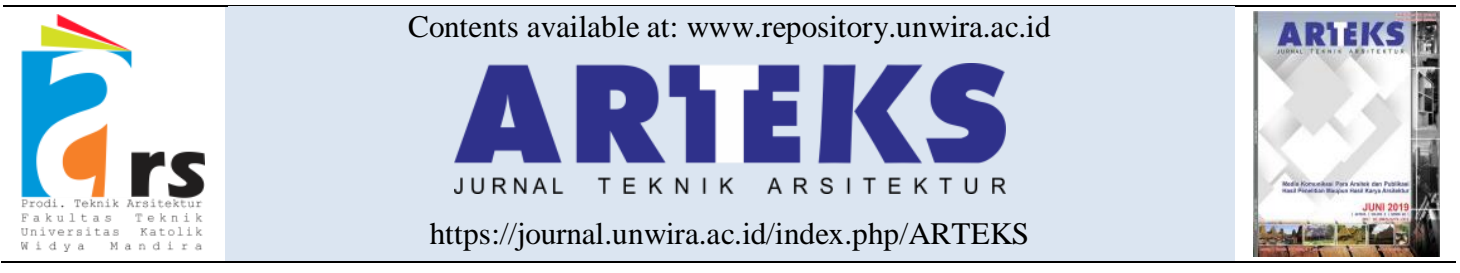

Volume 5 Issue 1 April 2020

doi: http://doi.org/10.30822/arteks.v5i1

\section{TABLE OF CONTENTS}

\section{Editorial}

Teori dalam penelitian arsitektur [Iwan Sudradjat]

$[1-6]$

\section{Article - Research}

Strategi adaptasi arsitektural pada rumah usaha di Jalan Tubagus Ismail, Bandung [Adrew Cokro Putra, Eko Bagus Prasetyo, Bima Rahmaputra, Agus Suharjono Ekomadyo]

Ekspresi-dasar arsitektural pada bangunan pusat kebudayaan, objek studi: Volkstheater Sobokartii di Semarang, Indonesia [Nabila Qirala Sukada, Purnama Salura]

Dinamika perubahan, transformasi, dan permanensi lingkungan Pasar Baru Bandung tahun 1906 - 2019 [Alifi Diptya Nidikara, Yohanes Karyadi Kusliansjah]

Identifikasi unsur-unsur arsitektural rumah kalang di Kotagede Yogyakarta [Maria Widianingtias. Sidhi Pramudito, Gerarda Orbita Ida Cahyandari]

Aktivitas di alun-alun sebagai ruang terbuka publik dengan konsep lapangan, kasus studi: Alunalun Bandung [Grace Putri Dianty, Yohanes Basuki Dwisusanto]

Peran sanro bola dalam tradisi membangun rumah tradisional Bugis di Kabupaten Soppeng [Asta Juliarman Hatta, Iwan Sudradjat]

Dominasi ragam akulturasi lokal-moderen pada bangunan Casablanka residence, Bali [Efraim Desprinto Lalu, Bachtiar Fauzy]

Identifikasi tingkat kebisingan serta indikasi dampak desain barrier hunian di tepi jalan raya [Frengky Benediktus Ola, Maria Christina Prasetya, Maria Risky Pratiwi Renwarin, Cecilia Kitti, Fiona Purwanto]

$[81-92]$

Penilaian kualitas estetika elemen arsitektural bangunan Kolonial di Jalan Basuki Rahmat, Malang [Syamsun Ramli, Herry Santosa, Antariksa]

$[93-106]$

Mandat (creadential) dalam budaya mitigasi bencana pada masyarakat Kampung Budaya Sindang Barang [Cahyo Septianto Hutomo, Agus Suharjono Ekomadyo, Muchi Juma Ameir] ...

$[107-120]$

Pengembangan kampung kota sebagai salah satu alternative tujuan wisata minat khusus [Paulus Bawole]

$[121-132]$

Analisis kriteria desain jalur pedestrian kawasan stasiun kereta api Padalarang [Alfred Wijaya, Sally Octaviana Sari] 